\title{
KEADAAN DARURAT PADA SAAT OLAH GERAK MEMASUKI ALUR PELAYARAN SEMPIT SUNGAI KAPUAS DI MT. ANGGRAINI EXCELLENT
}

\author{
Wardono $^{a}$ dan Vega Fonsula Andromeda ${ }^{b}$ \\ ${ }^{\mathrm{a}}$ Taruna (NIT.51145138.N) Program Studi Nautika PIP Semarang \\ ${ }^{\mathrm{b}}$ Dosen Program Studi Nautika PIP Semarang
}

\begin{abstract}
ABSTRAK
Keadaan darurat adalah keadaan di luar keadaan normal yang terjadi di atas kapal sehingga merugikan pihak kapal dan mempunyai tingkat kecenderungan dapat membahayakan jiwa manusia, harta benda, dan lingkungan dimana kapal berada. Metode penelitian yang digunakan dalam penelitian ini adalah metode deskriptif kualitatif. Teknik analisa data menggunakan metode fishbone analysis dan faulth tree analysis untuk menganalisa faktor-faktor yang mempengaruhi keadaan darurat pada saat memasuki alur pelayaran sempit dan mengatasi keadaaan darurat pada saat memasuki alur pelayaran sempit tiba-tiba main engine mati.

Berdasarkan hasil penelitian, dapat disimpulkan bahwa keadaan darurat pada saat olah gerak memasuki alur pelayaran sempit adanya masalah-masalah yang meliputi faktorfaktor yang mempengaruhi keadaan darurat dan main engine tiba-tiba mati saat pelaksanaan olah gerak memasuki alur pelayaran sempit. Cara yang dilakukan untuk mengatasi faktor-faktor tersebut dibutuhkan kesigapan dan pengetahuan yang luas dari perwira serta crew, khususnya pada perwira jaga sebagai perwira yang bertanggung jawab terhadap jam jaga harus tegas dalam mengambil keputusan dan memberi perintah.
\end{abstract}

Kata kunci: keadaan darurat, olah gerak,main engine mati, fishbone analysis, fault tree analysis

\section{PENDAHULUAN}

Transportasi laut merupakan suatu kebutuhan dan menjadi alternatif terbaik dalam rantai perdagangan dunia, oleh sebab itu pelayaran yang aman dan nyaman sangat dibutuhkan. Keselamatan pelayaran merupakan salah satu faktor yang mutlak yang harus dipenuhi agar kapal dapat beroperasi dengan baik. Apabila seluruh persyaratan keselamatan pelayaran terpenuhi maka seluruh awak kapal dapat bekerja dengan maksimal.

Agar pengoperasian kapal dalam berolah gerak memasuki alur pelayaran sempit dapat efektif, diperlukan perwira dengan manajemen yang baik. Selain pengoperasian kapal dalam berolah gerak dan dapat mengatasi keadaan darurat yang akan timbul, perwira harus mengetahui faktor-faktor penghambat serta pendukung pelaksanaan olah gerak kapal untuk memasuki alur pelayaran sempit atau kesalahan dalam memberikan tugas, wewenang, tanggung jawab serta perintah pada bawahan.

Berdasarkan pengalaman penulis selama praktek berlayar di MT. Anggraini Excellent, pada tanggal 06 Maret 2017 pada saat kapal berolah gerak memasuki alur pelayaran sempit sungai Kapuas di Pontianak dalam perjalanan masuk tibatiba mesin induk mati yang diduga akibat dari adanya penurunan pada tekanan bahan bakar menurut manual book pada main engine untuk tekanan normal adalah 3 $\mathrm{kg} / \mathrm{cm} 2$ (pada kondisi normal) sedangkan tekanan pada saat kejadian adalah 1 $\mathrm{kg} / \mathrm{cm} 2$ sehingga kapal terapung apung di tengah alur. Dalam keadaan seperti itu 
Wardono dan Vega Fonsula Andromeda

perwira serta crew melakukan pengawasan di sekitar posisi kapal untuk mengantisipasi ancaman-ancaman dari berbagai hal. Oleh karena itu penulis mengangkat permasalahan dengan judul "Pengawasan Keadaan Darurat Pada Saat Olah Gerak Memasuki Alur Pelayaran Sempit Sungai Kapuas Di MT. Anggraini Excellent".

Dari latar belakang masalah di atas penulis menemukan masalah yang ingin diungkapkan dalam penelitian ini, yaitu :

1. Faktor-faktor apa saja yang mempengaruhi keadaan darurat pada saat memasuki alur pelayaran sempit?

2. Bagaimana cara mengatasi keadaan darurat pada saat memasuki alur pelayaran sempit jika main engine tibatiba mati?

\section{KAJIAN PUSTAKA}

A. Kajian Pustaka

1. Pengertian Keadaan Darurat

Menurut Agus Hadi P, Emergency Prosedure dan SAR (2004: 01) Keadaan Darurat (Emergency Situation) adalah suatu keadaan di luar keadaan normal yang terjadi di atas kapal yang mempunyai tingkat kecenderungan akan dapat membahayakan jiwa manusia, harta benda, dan lingkungan dimana kapal berada.
Menurut
Badan
Diklat

Perhubungan, Personal Safety and Social Responsibility, Basic Safety Training Modul 4. Keadaan Darurat adalah keadaan yang lain dari keadaan yang lain dari keadaan normal yang mempunyai kecenderungan atau potensi tingkat yang membahayakan baik bagi keselamatan manusia, harta benda, maupun lingkungan.

2. Jenis-jenis keadaan darurat

Gangguan pada saat kapal berlayar dapat disebut sebagai keadaan darurat. Keadaan darurat adalah keadaan di luar keadaan normal yang cenderung dpat mengancam keselamatan awak kapal, kapal dan muatannya. Sehingga keadaan darurat itu dapat dicontohkan sebagai berikut:

a. Tubrukan Kapal di Laut (collision in the sea);

b. Ledakan / Kebakaran di Kapal (fire on the ship);

c. Kapal Kandas (grounding);

d. Kapal tenggelam / kebocoran (sinking / leakege);

e. Orang jatuh ke laut (man over boat);

f. Pencemaran (pollusion);

3. Pengertian Olah Gerak

Mengolah gerak kapal dapat diartikan sebagai penguasaan kapal, baik dalam keadaan diam maupun bergerak untuk mencapai tujuan pelayaran yang aman dan efisien, dengan mempergunakan sarana dan prasarana yang terdapat di kapal itu sendiri seperti mesin, kemudi, dan lain-lain.

Menurut Subandrijo, Olah Gerak dan Pengendalian Kapal (2015: 1) pada bab 1 disebutkan bahwa kemampuan sebuah kapal dalam berolah gerak dipengaruhi oleh beberapa faktor, adapun faktor tersebut baik yang ada pada kapal itu sendiri dari dalam (internal) maupun yang datang dari luar kapal (external).

Menurut Agus Hadi Purwantomo, Kumpulan Soal Jawab Teknik Pengendalian dan Olah Gerak Kapal (2007:1), faktor-faktor yang mempengaruhi pelaksanaan olah gerak kapal yaitu faktor yang berasal dari dalam kapal dan faktor yang berasal dari luar kapal.

4. Pengertian Alur Pelayaran Sempit

Pengertian dari alur peayaran sempit hasil kutipan yang diambil dari internet https://id.wikipedia.org/wiki/Alur_p 
elayaran "Alur pelayaran adalah perairan yang dari segi kedalaman, lebar, dan bebas hambatan pelayaran lainnya dianggap aman dan selamat untuk dilayari oleh kapal di laut, sungai atau danau. Alur pelayaran dicantumkan dalam peta laut dan buku Petunjuk Pelayaran serta diumumkan oleh instansi yang berwenang. Alur pelayaran digunakan untuk mengarahkan kapal masuk ke kolam pelabuhan, oleh karena itu harus melalui suatu perairan yang tenang terhadap gelombang dan arus yang tidak terlalu kuat".

\section{Pengertian Kapal}

Menurut Undang-Undang Nomor 17 Tahun 2008 tentang Pelayaran, "kapal" adalah kendaraan air dengan bentuk dan jenis tertentu, yang digerakkan dengan tenaga angin, tenaga mekanik, energi lainnya, ditarik atau ditunda, termasuk kendaraan yang berdaya dukung dinamis, kendaraan di bawah permukaan air, serta alat apung dan bangunan terapung yang tidak berpindah-pindah.

\section{B. Kerangka Berfikir}

Agar penulisan ini menjadi jelas dan dapat dipahami maka penulis akan memberi beberapa alasan tentang penulisan judul penelitian "Pengawasan Keadaan Darurat Pada Saat Olah Gerak Memasuki Alur Pelayaran Sempit Sungai Kapuas di MT. Anggraini Excellent". Berdasarkan pengamatan, pengalaman dan data-data yang diperoleh bahwa pengawasan keadaaan darurat pada saat olah gerak memasuki alur pelayaran sempit sangat diperlukan untuk menunjang dan juga memastikan bahwa proses olah gerak memasuki alur dalam keadaan aman.

Oleh karena itu untuk meningkatkan kesiapan dalam mengolah gerak kapal perlu diadakan pelatihan-pelatihan dengan tujuan agar dalam menghadapi keadaan darurat sesungguhnya tidak terjadi kerancuan dalam mengambil suatu keputusan. Dari penelitian ini, diharapkan agar setiap crew kapal dapat benar-benar mampu melaksanakan tugas dan tanggung jawab dalam melaksanakan tindakan menanggulangi keadaan darurat.

Di samping itu perwira kapal harus dapat mengidentifikasi keadaan darurat dengan cepat agar kerusakan yang ditimbulkan dapat dihindari. Peranan perwira kapal dalam memberikan tugas ataupun perintah kepada anak buah secara jelas adalah hal yang diharapkan, sehingga crew dapat bekerja lebih efektif dan terarah. Kualitas kepemimpinan sangat penting bagi setiap perwira dalam suatu organisasi ataupun kegiatan untuk mencapai tujuan.

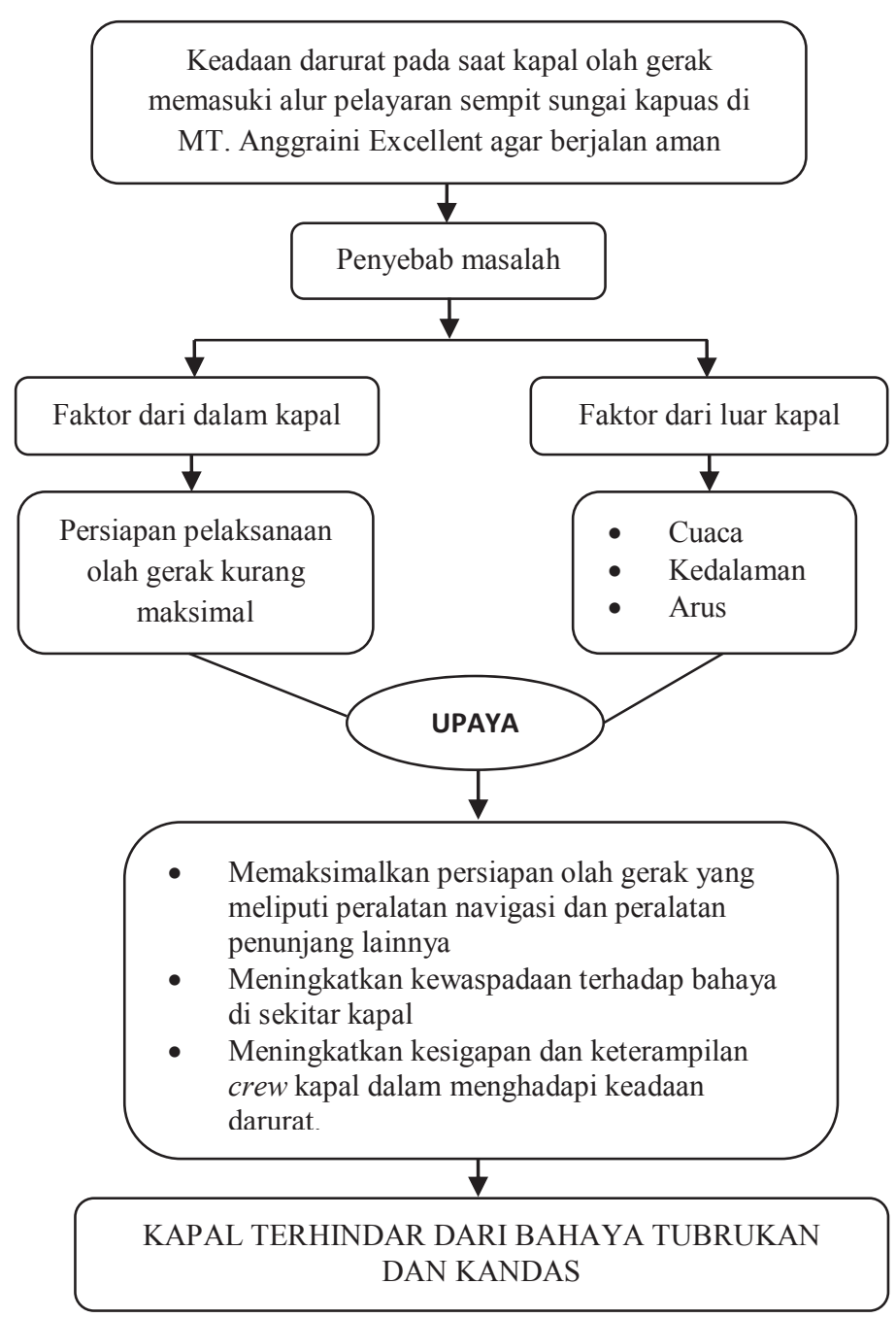


Wardono dan Vega Fonsula Andromeda

\section{METODOLOGI}

\section{A. Metode Penelitian}

Metode penelitian yang digunakan oleh penulis dalam penyampaian masalah adalah metode deskriptif kualitatif, untuk menggambarkan dan menguraikan objek yang diteliti.

\section{Metode Deskriptif}

Menurut Lexy J. Moleong, M.A, dalam buku Metode Penelitian (2004:06), mendefinisikan deskriptif adalah data yang dikumpulkan berupa kata-kata, gambar, dan bukan angka-angka. Hal ini disebabkan oleh adanya penerapan metode kualitatif. Selain itu semua yang dikumpulkan berkemungkinan menjadi kunci terhadap apa yang sudah diteliti. Penelitian ini selain mengandung hal-hal yang bersifat teori juga memuat hal-hal yang bersifat praktikum. Dalam pengertian bahwa selain ditulis dari beberapa literatur buku, juga bersumber dari obyek-obyek penelitian yang terdapat dalam buku.

2. Metode Kualitatif

Menurut Lexy J. Moleong, M.A, Metode Penelitian (2005:98), mendefinisikan metode kualitatif adalah pengamatan, wawancara, atau penelaahan dokumen. Metode kualitatif ini digunakan karena beberapa pertimbangan :

a. Menyesuaikan metode kualitatif lebih mudah apabila berhadapan dengan kenyataan jamak.

b. Metode ini menyajikan secara langsung hakikat hubungan antara peneliti dan responden.

c. Metode ini lebih peka dan lebih dapat menyesuaikan diri dengan banyak penajaman pengaruh bersama terhadap pola-pola nilai yang dihadapi.
B. Sumber Data

Pada penelitian ini penulis akan memberikan berbagai macam data yang bersifat kualitatif yang bersumber dari responden, baik secara lisan maupun secara tulisan berkaitan dengan objek yang penulis pelajari. Berbagai macam sumber data yang penulis pergunakan pada saat penyusunan penelitian adalah sebagai berikut:

1. Sumber Data Primer

Data primer dalam penyusunan penelitian ini adalah data yang didapat secara langsung dari sumbernya. Menurut Margono (2008:23), mendefinisikan data primer adalah data yang dikumpulkan langsung dari individuindividu yang diteliti. Dalam hal ini data yang diambil dengan cara pengamatan dan wawancara dengan orang-orang yang terlibat secara langsung pada materi atau hal-hal yang berhubungan dengan materi yang penulis perlukan.

2. Data Sekunder

Menurut Margono, Metodologi penelitian pendidikan (2008:23), mendefinisikan data sekunder adalah data yang ada dalam pustakapustaka. Data sekunder merupakan data yang diperoleh penulis sebagai data yang digunakan untuk mendukung atau melengkapi data yang sudah penulis dapatkan secara langsung. Data tersebut penulis dapatkan dari buku-buku dan hasil penelitian lain yang mempunyai hubungan dengan apa yang penulis pelajari.

C. Metode Pengumpulan Data

Metode pengumpulan data merupakan langkah yang paling strategis dalam penelitian, karena tujuan utama dari penelitian adalah mendapatkan data. Dalam penelitian ini, penulis menggunakan beberapa 
metode pengumpulan data, diantaranya sebagai berikut :

1. Metode Lapangan (field reasearch)

Penelitian lapangan adalah metode penelitian dengan menggunakan pengamatan secara langsung pada obyek yang diamati dan dilakukan pengamatan selama melaksanakan praktek laut di atas kapal, Sehingga data-data yang diperoleh dan berhasil dikumpulkan benar-benar sesuai dengan kenyataan. Penelitian lapangan dilakukan dengan cara :

a. Observasi (observation)

Observasi adalah pengamatan dan pencatatan secara sistematik terhadap gejala yang tampak pada objek penelitian. Metode yang digunakan oleh penulis berdasarkan pengalaman selama melaksanakan Praktek Laut di atas kapal MT. Anggraini Excellent selama 1 tahun 2 hari. Sehingga penulis dapat melihat dan mengalami secara langsung mengenai hal-hal yang perlu mendapatkan perhatian khusus serta hambatan yang akan timbul dalam pelaksanaan pengawasan keadaan darurat pada saat olah gerak memasuki alur pelayaran sempit di sungai Kapuas dan faktor-faktor yang menghambat serta upaya yang dilakukan untuk menyelesaikan faktor tersebut.

b. Interview (wawancara)

Menurut J. Moleong, MA, Metode Penelitian (2004:135), mendefinisikan interview adalah percakapan dengan maksud tertentu, percakapan itu dilakukan oleh dua pihak yaitu pewawancara yang mengajukan pertanyaan dan yang diwawancarai yang memberikan jawaban atas pertanyaan itu. Metode tersebut penulis lakukan untuk memperoleh data yaitu wawancara langsung dengan perwira kapal dan awak kapal tentang pengawasan keadaan darurat pada saat olah gerak memasuki alur pelayaran sempit di sungai Kapuas di MT. ANGGRAINI EXCELLENT.

1) Nakhoda (Master)

Sebagai pimpinan, yang bertanggung jawab terhadap seluruh kegiatan di atas kapal, sebagai wakil perusahaan dan sebagai penegak hukum.

2) Mualim I (chief officer)

Mualim I adalah perwia di atas kapal yang bertanggung jawab kepada Nakhoda dan perusahaan pelayaran mengenai muatan dan perawatan kapal.

3) Mualim II (second officer)

Mualim II adalah perwira di atas kapal yang bertanggung jawab kepada Nakhoda dan perusahaan pelayaran mengenai alat-alat navigator di anjungan.

4) Mualim III (third officer)

Mualim III adalah perwira di atas kapal yang bertanggung jawab kepada nakhoda dan perusahan pelayaran mengenai alat-alat keselamatan di atas kapal.

2. Metode Kepustakan

Menurut Nazir Moh, Metode Penelitian (2005:93), mendefinisikan kepustakaan adalah mengadakan survey terhadap data yang ada merupakan langkah yang penting sekali dalam metode ilmiah, memperoleh informasi dari penelitian terdahulu harus dikerjakan dan menelusuri literature yang ada serta menelaahnya secara tekun merupakan kerja kepustakaan yang sangat diperlukan dalam mengerjakan penelitian.

Riset kepustakaan juga disebut suatu sistem pengumpulan data dengan mencari sumber dalam 
Wardono dan Vega Fonsula Andromeda

berbagai buku mengenai keteranganketerangan yang dibahas dalam penelitian. Begitu juga dengan penulisan, selain melaksanakan riset lapangan juga melaksanakan riset kepustakaan guna mendapatkan keterangan yang akurat mengenai masalah yang akan dibahas. Riset penulisan itu penulis laksanakan dengan jalan mengumpulkan bukubuku yang berkenaan dengan keadaan darurat dan olah gerak kapal sewaktu praktek di atas kapal dan yang ada di dalam perpustakaan PIP Semarang.

\section{Teknik Analisa Data}

Menurut Lexy J. Moleong, Metode Penelitian (2004:103), Analisis data didefinisikan sebagai proses yang merinci usaha secara formal untuk menemukan tema dan merumuskan hipotesis (ide) seperti yang disarankan oleh data dan sebagai usaha untuk memberikan bantuan pada tema dan hipotesis itu.

Metode yang digunakan untuk menganalisa data dalam penelitian ini menggunakan metode fishbone analysis dan fault tree, dimana dalam penulisan penelitian ini untuk menganalisa dan membahas masalah-masalah yang ditemukan dalam penelitian. Pengamatan dan pandangan terhadap data yang ada mulai dari pokok permasalahan yang terjadi, membaca kumpulan data, dikaji berdasarkan teori-teori yang dapat memberikan pemecahan masalah yang terbaik sehingga permasalahan yang timbul dapat terselesaikan dengan solusinya.

1. Fishbone Analysis (analisa tulang ikan)

Diagram fishbone adalah salah satu metode yang digunakan dalam meningkatkan kualitas. Sering juga diagram ini disebut dengan diagram sebab-akibat atau cause effect diagram yang menggunakan data verbal (non-numerical) atau data kualitatif. Dikatakan diagram fishbone (tulang ikan) karena memang berbentuk mirip dengan tulang ikan yang moncong kepalanya menghadap ke kanan. Diagram ini akan menunjukkan sebuah dampak atau akibat dari sebuah permasalahan, dengan berbagai penyebabnya. Efek atau akibat dituliskan sebagai moncong kepala. Sedangkan tulang ikan diisi oleh sebab-sebab sesuai dengan pendekatan permasalahannya.

Dikatakan diagram cause and effect (sebab dan akibat) karena diagram tersebut menunjukkan hubungan antara sebab dan akibat. Berkaitan dengan pengendalian proses statistikal, diagram sebabakibat dipergunakan untuk menunjukkan faktor-faktor penyebab (sebab) dan karakteristik kualitas (akibat) yang disebabkan oleh faktor-faktor penyebab itu.

2. Metode Fault Tree Analyis (analisa pohon kesalahan)

Fault Tree Analysis (FTA) adalah suatu teknik yang digunakan untuk mengidentifikasi risiko terhadap terjadinya suatu permasalahan. Metode ini dilakukan dengan pendekatan yang bersifat top down, yang diawali dengan asumsi permasalahan (top event) kemudian merinci sebab-sebab suatu top event sampai pada suatu permasalahan dasar (root cause).

Tujuan dari metode Fault Tree Analysis adalah untuk mengidentifikasi akar penyebab dari permasalahan. Manfaat metode Fault Tree Analysis (FTA) adalah sebagai berikut:

a. Dapat menentukan faktor penyebab yang kemungkinan besar menimbulkan permasalahan; 
b. Dapat menentukan tahapan kejadian yang kemungkinan besar sebagai penyebab permasalahan;

c. Dapat menganalisa kemungkinan sumber-sumber resiko sebelum permasalahan timbul.

\section{DISKUSI}

\section{A. Gambaran Umum}

Sesuai dengan judul yang diangkat yakni "Pengawasan Keadaan Darurat Pada Saat Olah Gerak Memasuki Alur Pelayaran Sempit Sungai Kapuas di MT. Anggraini Excellent" maka sebagai deskripsi data akan dijelaskan tentang keadaan sebenarnya yang terjadi di kapal, sehingga dengan deskripsi ini penulis mengharapkan agar pembaca mampu dan bisa merasakan tentang semua hal yang terjadi selama penulis melaksanakan penelitian. Adapun hal-hal yang diamati adalah pengawasan pada saat kapal MT. Anggraini Excellent berolah gerak memasuki alur pelayaran sempit sungai Kapuas tiba-tiba mesin induk mati sehingga kapal tidak memiliki daya atau tekanan dari mesin induk dan mengakiatkan kapal mengapung-apung di alur. Dengan adanya penelitian ini diharapkan hubungan antara pokok permasalahan dengan metode pemecahannya akan lebih jelas, sehingga selanjutnya dapat dicari usaha dan upaya untuk menanggulangi masalah tersebut.

Data-data lain yang penulis dapatkan selama praktek layar di MT. Anggraini Excellent adalah pada saat itu kapal akan melakukan olah gerak memasuki alur pelayaran sempit di sungai Kapuas tiba-tiba mesin induk mati sehingga kapal berhenti di alur. Kejadian tersebut terjadi pada tanggal 06 Februari 2017 pada pukul 17.30 waktu setempat.

Menurut hasil wawancara dengan narasumber KKM (chief enginer), dikatakan bahwa:
"Terjadinya mesin induk mati setelah ditelusuri ternyata karena adanya filter bahan bakar yang kotor sehingga menghambat supply bahan bakar menuju ke mesin induk, yang mnyebabkan kotornya filter tersebut adalah tidak berfungsinya purifier sehingga bahan bakar dari tanki double bottom langsung menuju ke tanki setling dilanjutkan menuju ke tanki service dan dilanjutkan menuju ke main engine. Faktor penyebab tersumbatnya filter tersebut dikarenakan tidak dilakukan pembersihan pada filter secara berkala dan prosedur memasuki alur pelayaran sempit tidak dipenuhi”

\section{B. Analisis Data}

Pada proses analisis data, penulis menggunakan 2 Metode teknik analisa data yang tediri dari fishbone analysis dan Fault Tree Analysis (FTA). Metode fishbone analysis penulis gunakan untuk menganalisa faktor-faktor yang mempengaruhi keadaan darurat pada saat memasuki alur pelayaran sempit, dan metode FTA penulis gunakan untuk mencari solusi dalam mengatasi keadaan darurat pada saat memasuki alur pelayaran sempit tiba-tiba mesin induk mati. Berdasarkan analisa penelitian di atas kapal, penulis menemukan beberapa permasalahan yang berhubungan dengan olah gerak memasuki alur pelayaran sempit.

1. Faktor-faktor yang mempengaruhi keadaan darurat pada saat di alur pelayaran sempit.

Dalam menentukan faktor-faktor yang mempengaruhi keadaan darurat atau bahaya-bahaya tersebut penulis menggunakan metode fishbone analysis, karena sangat tepat untuk mencari penyebab suatu permasalahan. Pendekatan metode fishbone analysis yang digunakan untuk menjabarkan faktor-faktor keadaan darurat atau bahaya-bahaya tersebut adalah sebagai berikut:

a. Manusia; 
Wardono dan Vega Fonsula Andromeda
b. Alam;
c. Peralatan;
d. Lingkungan.

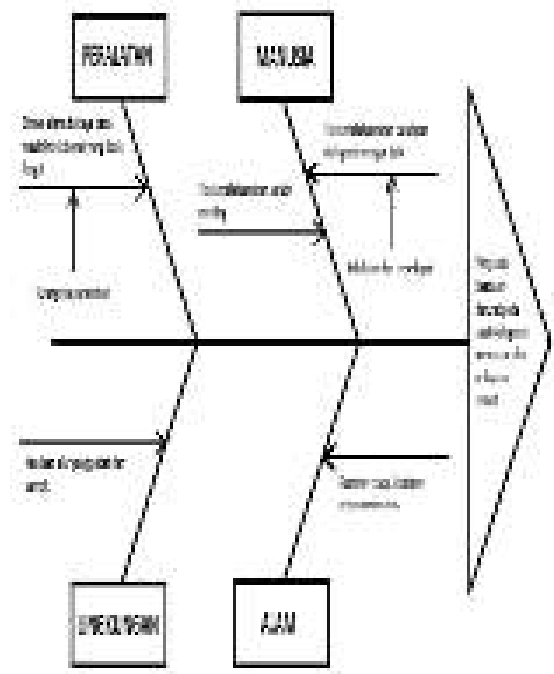

Gambar 1. Diagram fishbone analysis

Keterangan diagram :

\begin{tabular}{|c|l|}
\hline $\begin{array}{c}\text { Faktor yang } \\
\text { diamati }\end{array}$ & \multicolumn{1}{|c|}{ Masalah yang terjadi } \\
\hline Manusia & $\begin{array}{l}\text { Kurang maksimalnya persiapan } \\
\text { untuk pelaksanaan olah gerak } \\
\text { memasuki alur pelayaran sempit } \\
\text { sehingga kapal terjadi kendala, } \\
\text { saat di alur tiba-tiba mesin induk } \\
\text { mati. }\end{array}$ \\
\hline Alam & $\begin{array}{l}\text { Keadaan cuaca di perairan alur } \\
\text { sempit sangat berpengaruh besar } \\
\text { akan bahaya-bahaya yang akan } \\
\text { timbul seperti pengaruh dari arus } \\
\text { dan angin kapal akan bisa } \\
\text { terbawa keluar dari alur sehingga } \\
\text { dapat mengakibatkan kapal } \\
\text { kandas. }\end{array}$ \\
\hline Peralatan & $\begin{array}{l}\text { Kurangnya perawatan pada } \\
\text { sistem alarm pada mesin induk } \\
\text { sehingga banyak yang tidak } \\
\text { berfungsi saat terjadi problem } \\
\text { pada mesin induk. }\end{array}$ \\
\hline Lingkungan & $\begin{array}{l}\text { Kondisi alur pelayaran yang } \\
\text { padat dan sempit sangat besar } \\
\text { kemungkinan bahaya navigasi } \\
\text { akan kita jumpai seprti halnya } \\
\text { bahaya tubrukan dan kandas. }\end{array}$ \\
\hline
\end{tabular}

Setelah dilakukan analisa menggunakan fishbone diagram, didapat faktor-faktor yang mempengaruhi keadaan darurat atau bahaya-bahaya dari keadaan kapal tanpa daya atau mesin induk mati di tengah alur pelayaran sempit sungai Kapuas Pontianak Kalimantan Barat. Antara lain sebagai berikut:

1) Kurang maksimalnya persiapan olah gerak di perairan alur sempit sungai Kapuas Pontianak;

2) Pengaruh cuaca pada saat olah gerak di peraiaran alur pelayaran sempit;

3) Akibat kurang maksimalnya perawatan sistem alarm pada mesin induk;

4) Kondisi perairan yang sempit dan padat sangat besar kemungkinan bahaya-bahaya navigasi akan dijumpai.

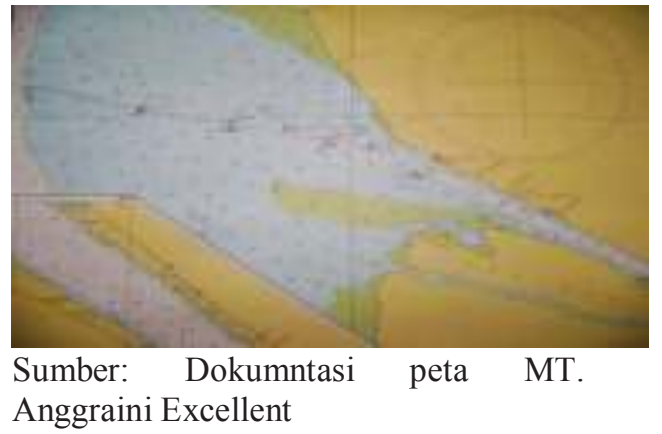

Gambar 2. Peta Alur Sungai Kapuas Pontianak

Berikut adalah penjelasan dari faktor-faktor di atas:

1) Kurang maksimalnya persiapan untuk pelaksanaan olah gerak memasuki alur pelayaran sempit sehingga kapal terjadi kendala saat berada di alur, tiba-tiba mesin induk mati dan terjadi keadaan darurat di atas kapal. Ini terjadi karena kelalaian dari crew saat melakukan persiapan olah gerak kurang teliti.

2) Keadaan cuaca di perairan alur sempit sangat berpengaruh besar akan bahaya-bahaya yang akan timbul seperti pengaruh dari arus 
dan angin. Angin sangat mempengaruhi olah gerak, terutama ditempat-tempat yang sempit dan olah gerak kapal terbatas, walaupun pada situasi tertentu angin dapat pula digunakan untuk mempercepat olah gerak kapal.

3) Kurangnya perawatan pada filter bahan bakar dan sistem alarm pada mesin induk sehingga mengakibatkan filter tersumbat dan tidak berfungsinya alarm pada mesin induk sehingga pada saat terjadi problem pada sistem bahan bakar di mesin induk tidak dapat terdeteksi dengan akurat.



Gambar 3. Sistem bahan bakar

4) Alur pelayaran yang padat dan sempit sangat besar kemungkinan bahaya navigasi akan kita jumpai seperti halnya bahaya tubrukan dan kandas. Pada perairan sempit, jika lunas kapal berada terlalu dekat dengan dasar perairan maka akan terjadi ombak haluan atau buritan serta penurunan permukaan air diantara haluan dan buritan disisi kiri atau kanan kapal serta arus bolak balik, sehingga mengakibatkan kapal dapat terjadi kandas di perairan yang dangkal tersebut.

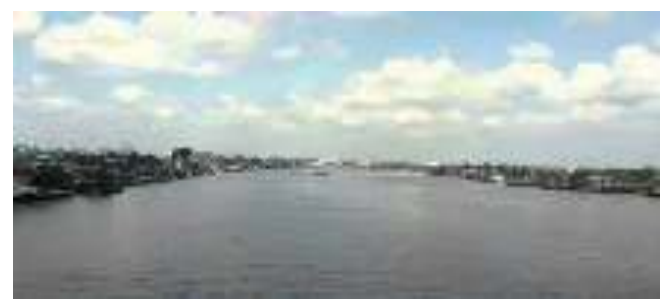

Gambar 4. Kondisi alur pelayaran sempit sungai Kapuas
2. Bagaimana cara mengatasi keadaan darurat pada saat memasuki alur pelayaran sempit jika main engine tiba-tiba mati

Dalam menentukan upaya yang harus dilakuakan untuk mengatasi keadaan darurat ketika memasuki alur pelayaran sempit jika main engine tiba-tiba mati, penulis menganalisa kembali penyebabpenyebab dari main engine tiba-tiba mati dengan menggunakan metode Fault Tree Analysis (FTA). Tujuannya adalah untuk mendapatkan akar penyebab permasalahan tersebut, sehingga nantinya dapat diketahui apa yang harus dilakukan untuk mengantasi keadaan darurat pada saat memasuki alur pelayaran sempit jika main engine mati. Sehingga nantinya dapat diketahui cara apa saja yang harus dilakukan untuk mengatasi keadaan darurat pada saat meemasuki alur pelayaran sempit tiba-tiba main engine mati dan kondisi kapal tetap aman berada di alur.




Wardono dan Vega Fonsula Andromeda

Tabel Kebenaran Pohon Kesalahan

\begin{tabular}{|c|c|c|}
\hline $\begin{array}{c}\text { Filter } \\
\text { bahan } \\
\text { bakar } \\
\text { tersumbat }\end{array}$ & $\begin{array}{c}\text { Faktor usia pada } \\
\text { mesin dan } \\
\text { peralatan } \\
\text { banyak yang } \\
\text { tidak berfungsi. }\end{array}$ & $\begin{array}{c}\text { Main engin } \\
\text { tiba-tiba mati }\end{array}$ \\
\hline 0 & 0 & 0 \\
\hline 0 & 1 & 1 \\
\hline 1 & 0 & 1 \\
\hline 1 & 1 & 1 \\
\hline
\end{tabular}

Dari analisa di atas, penyebab terjadinya main engine tiba-tiba mati adalah:

a. Filter bahan bakar tersumbat

Penyebab mesin induk mati dikarenakan oleh kotornya filter bahan bakar, dari penyebab tersebut mengakibatkan filter tersumbat dan mengakibatkan tekanan atau supply bahan bakar menuju ke mesin induk berkurang, karena tersumbatnya filter dapat mengurangi head statis pada sisi isap, sehingga sisi tekan berkurang dan mesin induk akan mati dengan sendirinya, karena kebutuhan bahan bakar pada mesin induk yang kurang mesin induk akan mati dengan sendirinya.

Faktor yang mnyebabkan tersumbatnya filter bahan bakar adalah kurangnya pengecekan atau perawatan pada filter, sebab dari permasalahan tersebut adalah kurangnya perawatan yang dilakukan secara berkala oleh crew, padahal saat masuk alur pelayaran sempit itu membutuhkan supply bahan bakar yang maksimal karena keadaan kapal sedang bermuatan full sedangkan navigasi sering ahead, dead, astern, jadi memang kondisi filter dan lain-lain harus dalam kondisi prima. Akibat dari permasalahan tersumbatnya filter bahan bakar sehingga mengakibatkan mesin induk mati, kapal terjadi keadaaan darurat dimana kapal terbawa oleh arus dan angin karena kapal tidak memiliki daya sehingga sangat mudah terdorong oleh kekuatan arus dan angin dari perairan tersebut, sampai akhirnya kapal hampir terjadi kandas karena dorongan dari arus dan angin tersebut namun dapat dicegah dengan sigap.

Nakhoda memerintahkan kepada crew yang berada di deck untuk menurunkan jangkar dengan cepat sehingga kapal dapat tertahan oleh jangkar dan kapal aman dari ancaman kandas di perairan tersebut. Dari permasalahan mesin induk mati yang terjadi pada kapal tanker MT. Anggraini Excellent mengakibatkan proses olah gerak kapal saat akan masuk ke pelabuhan terganggu dan menghambat traffic yang berada di alur tersebut.

b. Faktor usia pada mesin dan peralatan banyak yang tidak berfungsi

Faktor usia pada mesin sangat berpengaruh terhadap matinya mesin induk saat berada di alur karena adanya beberapa sistem alarm pada mesin induk yang tidak berfungsi sehingga pada saat terjadi kekurangan bahan bakar dikarenakan filter tersumbat tidak terdeteksi secara akurat sehingga Masinis jaga kesulitan dalam mendeteksi dan akibatnya mesin induk tiba-tiba slow down dan mati. Sebenarnya kurangnya tekanan bahan bakar tersebut terasa dan indikator bahan bakar dapat terlihat jika berkurang melalui indikator sensor di engine room, namun karena kondisi mesin sudah tua dan banyak 
peralatan atau sistem alarm yang tidak berfungsi sehingga data atau peringatan yang dikirimkan tidak bisa terkirim dengan akurat.

Dari permasalahan tersebut dapat diambil kesimpulan bahwa faktor penyebabnya adalah dari faktor manusia dan faktor peralatan. Faktor yang disebabkan oleh manusia yaitu akibat dari kelalaian crew karena tidak dilakukan pembersihan pada filter secara berkala sehingga kotoran yang berada pada filter menumpuk terlalu banyak dan menghambat saluran bahan bakar menuju ke mesin induk serta tidak melakukkan patroli ke local side mesin untuk mengecek secara langsung tekanan bahan bakar saat maneuvering. Untuk faktor yang disebabkan oleh peralatan yaitu karena faktor usia dari mesin yang sudah tua sehingga peralatan banyak yang tidak berfungsi atau alat pendeteksi atau alarm tidak dapat bekerja dengan baik serta kurangnya pengontrolan tiap peralatan mesin terutama sensor-sensor yang penting termasuk tekanan bahan bakar.

\section{Pembahasan}

1. Faktor-faktor yang mempengaruhi keadaan darurat

a. Kurang maksimalnya persiapan untuk pelaksanaan olah gerak memasuki alur pelayaran sempit sehingga kapal terjadi kendala saat berada di alur, tiba-tiba mesin induk mati dan terjadi keadaan darurat di atas kapal. Ini terjadi karena kelalaian dari crew saat melakukan persiapan olah gerak kurang teliti. Berdasarkan pengamatan yang dilakukan penulis selama melaksanakan praktek laut di kapal MT. Anggraini Excellent diketahui bahwa persiapan olah gerak memasuki alur pelayaran sempit kurang teliti dalam pelaksanaan persiapan $(\mathrm{OHN})$.

Pada saat persiapan penulis menjumpai kurang ketelitian dari crew engine dalam menyiapkan pengecekan mesin saat OHN. Dari kurang ketelitian tersebut mengakibatkan kapal berhenti pada saat di alur dikarenakan mesin induk mati akibat filter pada bahan bakar tersumbat kotoran sehingga supply bahan bakar kurang sehingga tekanan menjadi turun dan mengakibatkan mesin induk mati dengan tibatiba. Karena sistem alarm pada kapal MT. Anggraini Excellent banyak yang tidak berfungsi sehingga pada keadaan tersebut tidak bisa terdeteksi bahwa supply bahan bakar kurang atau tekanan turun. Pada mesin induk kapal MT. Anggraini Excelent jika sudah masuk angin dalam hal ini yang berhubungan dengan supply bahan bakar ke tiap-tiap silinder sulit untuk dihidupkan kembali, sehingga crew mesin harus kerja ekstra agar bahan bakar bisa masuk ke semua ruang bakar pada tiap-tiap silinder. Dari kejadian tersebut mengakibatkan kapal mengapung-apung di alur sehingga banyak faktor yang mempengaruhi keadaan darurat atau timbul bahaya-bahaya pada keadaan tersebut.

b. Keadaan cuaca di perairan alur sempit sangat berpengaruh besar akan bahaya-bahaya yang akan timbul seperti pengaruh dari arus dan angin. Angin sangat mempengaruhi olah gerak, terutama ditempat-tempat yang sempit dan sulit dalam keadaan kapal kosong, walaupun pada situasi tertentu angin dapat pula digunakan untuk mempercepat 
olah gerak kapal. Arus adalah gerakan air dengan arah dan kecepatan tertentu, menuju kesuatu tempat tertentu pula. Dikenal arus tetap dan arus tidak tetap. Rimban yang disebabkan oleh arus, tergantung dari arah dan kekuatan arus dengan arah dan kecepatan kapal. Semua benda yang terapung di permukaan arus dan didalamnya, praktis akan bergerak dengan arah dan kekuatan arus tersebut. Di perairan bebas pada umumnya arus akan menghanyutkan kapal, sedangkan di perairan sempit atau ditempat-tempat tertentu arus dapat memutar kapal. Pengaruh arus terhadap olah gerak kapal, sama dengan pengaruh angin. Jadi pengaruh arus dan angin pada kapal akan sangat besar pengaruhnya sehingga seorang nakhoda atau perwira jaga harus benar-benar menguasai arah arus dan angin agar kapal tetap dalam kondisi aman dan tetap berada di alur karena jika tidak menguasai kapal dapat terbawa dan keluar dari alur karena tekanan dari arus dan angin sehingga dapat mengakibatkan kapal kandas.

c. Kurangnya perawatan sistem alarm pada mesin induk sehingga mengakibatkan tidak berfungsinya alarm pada mesin induk pada saat terjadi problem pada mesin induk tidak dapat terdeteksi secara akurat. Faktor usia pada mesin atau alarm juga mempengaruhi tidak berfungsinya alarm dan faktor keterbatasan spare untuk onderdil di atas kapal sehingga untuk dilakukan perbaikan harus menunggu onderdil yang rusak dibelikan oleh pihak perusahaan. Sehingga dari faktor-faktor tersebut pihak crew melakukan perawatan kurang maksimal dan melakukan perawatan sesuai prosedur dan peralatan seadanya yang berada di atas kapal. Akibat dari faktor tersebut kapal tidak bisa maksimal saat beroperasi dan sering terjadi problem. Alat deteksi alarm yang tidak memadai ini atau bisa disebut tidak layak pakai dikarenakan alat tersebut sudah tidak berfungsi dan sepantasnya alat deteksi alarm pada main engine seperti itu harus segera diganti dengan alat deteksi yang baru. tetapi kendala yang dihadapi adalah kurangnya perhatian perusahaan akan pengadaan alat deteksi alarm tersebut mengingat bahwa pentingnya peranan alat deteksi alarm pada main engine sangatlah membantu dalam pencegahan bahaya atau terjadi problem pada main engine dan juga membantu keselamatan. maka agar alat deteksi alarm pada main engine memadai atau layak pakai guna pelayaran aman dari bahaya yang terjadi, maka dilakukan tindakantindakan agar alat deteksi alarm memadai. Tindakan-tindakan tersebut adalah:

1) Memberitahukan kepada perusahaan pelayaran akan pentingnya peranan alat deteksi alarm pada main engine di atas kapal;

2) Menunjukkan barang bukti bahwa alat tersebut sudah tidak memadai atau tidak layak pakai;

3) Ketegasan nakhoda terhadap perusahaan agar alat deteksi alarm tersebut segera diganti dengan yang baru, mengingat alat deteksi alarm tersebut sudah tidak dapat berfungsi dengan baik. 
Dari ketiga tindakan tersebut diharapkan alat deteksi alarm dapat memadai dan layak pakai sehingga peranan alat deteksi alarm pada main engine dalam pencegahan bahaya kerusakan atau problem pada main engine di atas kapal dapat berjalan dengan baik untuk dapat menunjang pelayaran yang aman terhadap bahaya atau kerusakan pada main engine di atas kapal.

d. Kondisi alur pelayaran yang padat dan sempit sangat besar kemungkinan bahaya navigasi akan kita jumpai seperti halnya bahaya tubrukan dan kandas. Pada perairan sempit, jika lunas kapal berada terlalu dekat dengan dasar perairan maka akan terjadi ombak haluan atau buritan serta penurunan permukaan air diantara haluan dan buritan disisi kiri atau kanan kapal serta arus bolak balik. Hal ini disebabkan karena pada waktu baling-baling bawah bergerak ke atas terjadi pengisapan air yang membuat lunas kapal mendekati dasar perairan, terutama jika berlayar dengan kecepatan tinggi, maka kapal akan terasa menyentaknyentak dan dapat mengakibatkan kemungkinan menyentuh dasar. Gejala penurunan tekanan antara dasar laut dengan lunas kapal berbanding terbalik dengan kuadrat kecepatannya. Kondisi tempat perairan yang ramai akan mengakibatkan kapal sulit untuk mengolah gerak sehingga untuk dapat mengolah gerak kapal diperlukan kondisi perairan yang tidak begitu ramai.

2. Cara untuk mengatasi keadaan darurat mesin induk mati pada saat kapal berolah gerak memasuki alur pelayaran sempit : a. Tindakan yang dilakukan oleh crew kapal

Cara yang dilakukan untuk mengatasi keadaan darurat pada saat kapal berolah gerak memasuki alur pelayaran sempit tiba-tiba mesin induk mati sebagai berikut:

1) Dilakukan safety meeting sebelum melakukan kegiatan atau pekerjaan yang bertujuan untuk memberikan arahan kepada seluruh crew dan laporan kondisi peralatan terakhir dioperasikan.

2) Pada saat pelaksanaan $\mathrm{OHN}$ seluruh crew yang bertugas harus benar-benar melakukan penngecekan secara menyeluruh dan dilakukan pengetesan pada peralatan yang digunakan untuk olah gerak yang bertujuan untuk mengetahui kondisi dari peralatan tersebut, karena dalam pelaksanaan olah gerak sangat diperlukan kondisi mesin yang prima untuk kelancaran pelaksanaan olah gerak.

3) Crew yang bertanggung jawab pada saat persiapan olah gerak harus melakukan pengecekan secara menyeluruh dan lebih teliti agar tidak terjadi kesalahan dalam mempersiapkan mesin untuk melakukan olah gerak.

4) Setiap melaksanakan pengecekan crew harus membawa ceklist pengecekan tiap permesinan dan memastikan bahwa seluruh daftar yang terdapat di dalam ceklist telah dilaksanakan dengan benar dan mesin dalam kondisi baik dan siap untuk melakukan olah gerak.

5) Setelah dilakukan pengecekan keseluruhan oleh 
Wardono dan Vega Fonsula Andromeda

crew selanjutnya dilaporkan kepada KKM (chief enginer) agar KKM mengetahui bahwa mesin telah selesai dilakukan pengecekan menyeluruh dan mesin dalam kondisi baik dan siap untuk melakukan olah gerak.

6) Setelah KKM mendapatkan laporan dari crew yang bertugas untuk melakukan pengecekan selanjutnya tugas KKM melakukan pngecekan ulang untuk memastikan lagi bahwa mesin benar-benar sudah dalam kondisi baik dan siap untuk melakukan olah gerak.

7) Setelah itu KKM melaporkan ke anjungan bahwa mesin sudah siap untuk melakukan olah gerak memasuki alur pelayaran sempit di sungai Kapuas Pontianak.

8) Selanjutnya nakhoda melaporkan kepada pihak pelabuhan atau kepanduan bahwa kapal sudah siap untuk melakukan olah gerak.

9) Selanjutnya kapal standby engine hingga pandu (pilot) datang dan naik di anjungan, olah gerak dapat dimulai menunggu perintah dari pandu.

10) Setelah pandu naik ke anjungan maka nakhoda menyerahkan komando kepada pandu untuk membawa kapal memasuki alur.

11) Selanjutnya kapal siap untuk berolah gerak di alur pelayaran sempit sungai Kapuas Pontianak.

Kapal pada saat kondisi mesin induk mati di alur tidak memiliki daya sama sekali sehingga kapal mengapung-apung di alur dan sangat berbahaya jika keadaan tersebut tidak segera diatasi karena kapal akan mudah terbawa oleh arus dan angin yang memiliki tekanan yang kuat sedangkan kapal tidak melmiliki tekanan sama sekali. Dalam kedaaan tersebut, kapal dengan cepat terseret oleh arus dan angin sehingga kapal hampir ke luar dari alur dan hampir saja kapal kandas namun dengan tegas nakhoda memerintahkan kepada crew yang bertugas di deck atau bostwain pada saat itu sedang standby untuk segera menurunkan jangkar agar kapal dapat tertahan dari tekanan arus dan angin sehingga kapal tidak keluar dari alur dan tidak terjadi kandas. Setelah jangkar sudah diturunkan, nakhoda dan perwira jaga di anjungan melakukan pengawasan secara terus menerus dan melakukan pengecekan kedalaman perairan dengan menggunakan cara manual untuk mendapatkan hasil yang nyata karena jika mengandalkan dari peralatan navigasi atau echosonder ada kemungkinan data yang didapatkan tidak sesuai karena peralatan elektronik terkadang terjadi eror. Setelah dilakukan pengecekan kedalaman perairan dan dinyatakan aman selanjutnya perwira jaga kembali untuk melakukan pengawasan guna mengantisipasi keadaankeadaan yang akan muncul karena pengaruh dari kondisi alam dan lingkungan di sekitar perairan. Selanjutnya diinformasikan kepada pihak pelabuhan bahwa kapal telah terjadi trouble pada saat kapal bergerak memasuki alur tiba-tiba main engine mati dan disebutkan 
posisi kapal, data kapal serta kerusakan kapal agar dapat diinformasikan kepada kapalkapal yang akan melintas di alur tersebut agar bisa bertahan terlebih dahulu sampai kapal dapat nyala kembali guna mengatasi keadaan-keadaan bahaya yang tidak kita inginkan seperti halnya tubrukan, kandas dan lain-lain.

Akibat dari kejadian tersebut lalu lintas di perairan tersebut jadi terhambat sehingga banyak pihak yang dirugikan atau mendapatkan efek dari permasalahan yang ada. Setelah main engine sudah dapat nyala kembali sesegera mungkin agar jangkar yang diturunkan segera dinaikkan untuk melanjutkan perjalanan memasuki alur menuju pelabuhan. Selanjutnya dilaporkan kembali kepada pihak pelabuhan bahwa kapal telah selesai perbaiakan dan mesin sudah dapat nyala kembali sehingga kapal dapat melanjutkan perjalanan kembali guna diinformasikan kepada kapalkapal yang akan melintas di alur tersebut agar dapat dilakukan persiapan untuk melanjutkan perjalanan/olah gerak.

\section{KESIMPULAN}

Berdasarkan pada hasil observasi di lapangan serta dari hasil uraian pembahasan mengenai pengawasan keadaan darurat pada saat olah gerak memasuki alur pelayaran sempit sungai Kapuas Pontianak di MT. Anggraini Excellent dapat diambil kesimpulan sebagai berikut:

1. Dari beberapa faktor yang mempengaruhi keadaan darurat pada saat olah gerak memasuki alur pelayaran sempit yang meliputi faktor manusia, alam, peralatan dan lingkungan dimana faktor-faktor tersebut harus diperhatikan karena dapat membahayakan kapal saat melakukan olah gerak dimana kapal dapat terjadi tubrukan ataupun terjadi kandas jika kita lalai atau tidak memperhatikan faktor-faktor tersebut.

2. Cara yang dilakukan untuk mengatasi keadaan darurat pada saat kapal berolah gerak memasuki alur pelayaran sempit tiba-tiba main engine mati yaitu perwira langsung melakukan pengecekan pada mesin untuk mendeteksi kerusakan yang terjadi pada mesin sehingga kapal dapat segera diperbaiki. Dalam keadaan darurat sangat dibutuhkan kesigapan dari perwira kapal dalam mengatasi keadaan darurat tersebut, sehingga kerusakan dengan cepat dapat diketahui dan dapat segera diperbaiki. Jadi seorang perwira harus memiliki pengetahuan yang luas serta kesigapan dalam setiap mengatasi keadaan darurat di atas kapal agar tidak memakan korban jiwa saat terjadi keadaan darurat dan tidak merugikan perusahaan serta pihak-pihak yang bersangkutan.

Sebagai langkah perbaikan di masa mendatang, penulis menyarankan beberapa hal yang diharapkan dalam pelaksanaan olah gerak memasuki alur pelayaran sempit dapat berjalan dengan lancar dan aman.

1. Disarankan untuk seluruh perwira atau crew kapal agar selalu memperhatikan faktor-faktor yang mempengaruhi keadaan darurat pada saat pelaksanaan olah gerak memasuki alur pelayaran sempit agar dapat berjalan dengan lancar dan aman. Dan selalu menyiapkan peralatan pendukung setiap akan berolah gerak untuk menghindari problem atau masalah-masalah yang dapat menghambat pelaksanaan olah gerak yang disebabkan oleh faktorfaktor dari dalam ataupun dari luar kapal yaitu mesin atau peralatan pendukung lainya untuk pelaksanan olah gerak kapal. 
Wardono dan Vega Fonsula Andromeda

2. Disarankan para perwira kapal bagian mesin selalu menjalankan maintenance plan bagi mesin induk maupun mesin pendukung untuk mesin induk agar selalu siap digunakan kapanpun dan dimanapun tanpa mengalami suatu kendala dan untuk perwira deck disarankan untuk selalu melakukan perawatan dan pengecekan peralatan pendukung olah gerak agar peralatan dapat digunakan dengan baik dan harus dilakukan pelatihan-pelatihan penanggulangan keadaan darurat sehingga jika terjadi keadaan darurat yang sebenarnya dapat diatasi dengan baik dan aman. Tujuan dilakukan pelatihan penanggulangan keadaan darurat adalah untuk melatih kesigapan crew dan mengurangi rasa panik dalam mengatasi keadaan darurat tersebut.

\section{DAFTAR PUSTAKA}

Badan Diklat Perhubungan, Personal Safety and Socia Responsibility. Basic Safety Trining Modul 4

Collision Regulation 1972 Aturan 9 Tentang Alur Pelayaran Sempit

https://id.wikipedia.org/wiki/Alur_pelayar an

https://malikazisahmad.wordpress.com/20 12/01/13/ pengertian-pengawasan/

Margono. 2008. Metodologi Penelitian Pendidikan. Jakarta: Transmedia

Moleong, Lexy J. 2004. Metodologi Penelitian Kualitatif. Bandung: Remaja Rosdakarya

$\begin{array}{llr} & 2005 . & \text { Metodologi } \\ \text { Penelitian } & \text { Kualitatif. } & \text { Bandung: } \\ \text { Remaja Rosdakarya } & \end{array}$

Nazir. 2005. Metode Penelitian. Bogor:

Purwantomo, Agus Hadi. 2004. Emergency Prosedure dan SAR. PIP Semarang . 2007. Kumpulan Soal Jawab Teknik Pengendalian dan Olah Gerak Kapal. PIP Semarang

Schermerhorn. 2002. Controlling is the process of measuring performance and taking action to ensure desired results

Stoner, Freeman \& Gilbert. 2005. The process of ensuring that actual activities conform the planned activities

Subandrijo, Joko. 2015. Olah Gerak dan Pengendalian Kapal. PIP Semarang

Undang-Undang Nomor 17 Tahun 2008 Tentang Pelayaran

\footnotetext{
Ghalia Indonesia
} 